\title{
The role of the fern test in the treatment of rhinitis
}

\section{El papel de la prueba de "helecho" en el tratamiento de la rinitis}

Matteo Gelardi, ${ }^{1}$ Giuseppe Porro, ${ }^{1}$ Nicola Quaranta, ${ }^{1}$ Brigida Sterlicchio, ${ }^{1}$ Michela Silvestri, ${ }^{2}$ Giorgio Ciprandi ${ }^{3}$

\begin{abstract}
Background: The fern test is a method for assessing the characteristics of the nasal section in the treatment of patients with mucous dysfunction of the airway.

Objective: The aim of this study was to investigate the role of the fern test in patients with rhinitis and to assess the classification of each type of rhinitis (types I-IV) in clinical practice.

Methods: A cross-sectional study, which included consecutive patients from a third level Rhinology Unit, worked with 182 patients with rhinitis and 30 healthy subjects as control. The patients were subdivided according to their type of rhinitis: allergic rhinitis (59), infectious rhinitis (32), polyps (31), NARES (Non-allergic rhinitis with eosinophilia syndrome) (30) and NARNE (non-allergic rhinitis with neutrophils) (30).

Results: The control subjects had only type I or II rhinitis, whereas patients with rhinitis usually showed type III or IV. Allergic rhinitis and nasal polyps had the most serious deterioration according to the fern test (type IV).

Conclusions: The fern test is effective for assessing mucus alterations in patients with rhinitis and it could be included as a new parameter in the study of rhinitis as a potential biomarker of the function of damaged epithelial cells.
\end{abstract}

Keywords: Rhinitis; Fern test; Inflammation of the mucosa

How to cite this article: Gelardi M, Porro G, Quaranta N, Sterlicchio B, Silvestri M, Ciprandi G. The role of the fern test in the treatment of rhinitis. Rev Alerg Mex. 2019;66(2):184-191

ORCID

Matteo Gelardi, 0000-0003-4406-0008; Giuseppe Porro, 0000-0003-2860-7608; Nicola Quaranta, 0000-0001-6214-2336; Brigida Sterlicchio, 0000-0002-6606-4811; Michela Silvestri, 0000-0003-4804-2421; Giorgio Ciprandi, 0000-0001-7016-8421

${ }^{1}$ University of Bari Aldo Moro, Department of Basic Medical Science, Neuroscience and Sensory Organs, Bari, Italy

${ }^{2}$ Istituto Giannina Gaslini, Genoa, Italy

${ }^{3}$ Ospedale Policlinico San Martino, Genoa, Italy
Correspondence: Giorgio Ciprandi.

gio.cip@libero.it

Received: 2018-08-28

Accepted: 2019-01-24

DOI: $10.29262 /$ ram.v66i2.544 


\section{Resumen}

Antecedentes: La prueba de "helecho" es un método que sirve para evaluar las características de la secreción nasal en el tratamiento de pacientes con disfunción de la mocosa de la vía aérea. Objetivo: El objetivo del presente estudio fue investigar el papel de la prueba de helecho en pacientes con rinitis y evaluar la clasificación de cada tipo de rinitis (tipos I a IV) en la práctica clínica.

Métodos: Estudio transversal en el que se incluyeron pacientes consecutivos de una unidad de rinología de tercer nivel. Se incluyeron 182 pacientes con rinitis y 30 sujetos sanos como controles. Los pacientes se subdividieron según el tipo de rinitis: alérgica (59), infecciosa (32), pólipos (31), rinitis eosinofílica no alérgica (30) y rinitis no alérgica con neutrófilos (30).

Resultados: Los sujetos control solo presentaron rinitis tipo I o II, mientras que los pacientes con rinitis generalmente mostraban tipo III o IV. La rinitis alérgica y los pólipos nasales tuvieron el deterioro más grave según la prueba de helecho (tipo IV).

Conclusiones: La prueba de helecho es efectiva para evaluar las alteraciones del moco en pacientes con rinitis y podría incluirse como un nuevo parámetro en el estudio de la rinitis como biomarcador potencial de la función de las células epiteliales dañadas.

Palabras clave: Rinitis; Prueba de "helecho"; Inflamación de la mucosa

\section{Abbreviations and acronyms}

$A R$, allergic rhinitis

MGG, May-Grünwald-Giemsa
NARES, non-allergic rhinitis with eosinophilia

NARNE, non-allergic rhinitis with neutrophils

\section{Background}

Mucus is a complex, viscoelastic, and adherent secretion that is produced and secreted by specialized goblet cells and mucous cells in the columnar epithelia that line the lumen of all the mucosa that are exposed to the external environment. ${ }^{1,2}$ In particular, mucus covers the inner linings of organs of the respiratory tract, the gastrointestinal tract, the reproductive tract, and the ocular surface. The concept of mucus is very old as its existence was already known from the time of the Ancient Greeks: phlegm was one of 4 humors. Mucus is widely produced in both kingdoms, plant and animal. ${ }^{3}$

From a physiological point of view, mucus carries out many protective functions for the underlying epithelia, such as mucosal lubrication, which is useful for material transport and cellular hydration of epithelial cells, mainly in the respiratory tract, eyes and mouth, which are exposed directly to the drying evaporative effects of air, and it provides a barrier against noxious agents and exposure to pathogens by trapping them. ${ }^{4}$ It also works as a cleansing transport, in which the external particles that are trapped in the mucus layer can be eliminated from organ cavities by cilia-facilitated expulsion of the mucus layer ${ }^{5}$ and provides a selectively permeable gel layer for the diffusion, exchange and absorption of gases (eyes and lungs) and nutrients (gastrointestinal tract) with the underlying epithelium. ${ }^{6}$

The rheology of nasal mucus deserves proper attention in clinical practice. ${ }^{7,8}$ From a chemical point of view, mucus should be seen as an integrated structure of biopolymers. The physical characteristics of mucus are complex, for example; it is a non-Newtonian fluid, and its physical characteristics range from a viscous liquid to an elastic solid. Mucus can be measured considering its consistency by viscosity (resistance to flow) and elasticity (stiffness). It must be noted that impaired mucus rheology may have significance on its functions, including lubrication, barrier, and defense against infective agents and noxious substances. ${ }^{8}$ 
Mucus is a thixotropic gel that is able to properly respond to shear stress. This ability depends on its composition. The components of mucus are mucins, DNA fragments, lipids, ions, proteins, cells, cellular debris, and water. ${ }^{9,10}$ In this regard, mucins are the most important component of the mucus as it is formed by cross-linked, bundled, and entangled mucin fibers which are produced and secreted by both goblet cells and sero-mucinous glands.

The bio-rheological properties of the nasal mucus are the cohesive forces, the load-bearing capacity, the spinnability, the thixotropy, the creep, and the adhesiveness. This complexity may easily explain how disorders could significantly affect the composition and function of nasal mucus. Infections, inflammatory disorders (including allergic and non-allergic infiltrates), polyps, drugs, and primary mucus defects may significantly alter the composition and function of mucus.

The properties of mucus may be assessed by using sophisticated tests, but a simple way could be represented by the nasal cytology. Long time ago, Papanicolaou proved that some cervical mucus that was spread on a slide and left to dry was able to crystallize with a characteristic shape, like an "arborization": a fern-like reaction. ${ }^{11} \mathrm{He}$ brilliantly conceived that this phenomenon could depend on the ovulation time as a reflection of the estrogenic activity that was able to affect the characteristics of the mucus. Further on, it was proven, by inducing the mucus-fern phenomenon, ${ }^{12,13}$ that the alterations of mucus, depending on the cycle of sexual hormones, occurred also in other mucus-secreting surfaces of the body; including the nose, salivary glands, and lacrimal glands. Abou-Shabanah and Plotz proved that the fern reaction depended on electrolyte, protein and/or saccharide concentrations..$^{14}$ So, the fern test was used to assess the characteristics of mucus in several disorders. Rolando et al. defined a scoring system to assess the fern test ${ }^{15}$ and reported fern impairment in different disorders at an ocular level. ${ }^{16,17}$ These outcomes were confirmed by further studies that were always conducted at an ocular level, ${ }^{18,19}$ so the fern test is commonly used in clinical practice in an ophthalmological setting. However, only another study considered the fern phenomenon in the nose: it compared nasal and cervical mucus. The authors concluded that mucus is an ancestral biological component, but they did not speculate about nasal disorders. ${ }^{20}$ Thus, we aimed to investigate the role of the fern test in patients with rhinitis in clinical practice.

\section{Methods}

Globally, 182 consecutive patients (102 males and 80 females, mean age: $43.15 \pm 19.03$ years) with rhinitis were visited at the Rhinology Unit because of their intensive treatment and they were included in this study.

The inclusion criteria were:

- Adult men and women.

- Documented diagnosis of rhinitis, including allergic rhinitis, infectious rhinitis, non-allergic rhinitis (NARES or NARNE), or nasal polyps.

- Presence of nasal symptoms.

The exclusion criteria were:

- Concomitant comorbidities and chronic illnesses that could interfere in the interpretation of the findings.

- Current treatments able to interfere in the interpretation of the findings. In addition, 30 healthy subjects were included in the study.

The Review Board approved the procedure and a written informed consent was given by all participants.

A nasal endoscopy was carried out with a 3.4 $\mathrm{mm}$ diameter flexible fiberoscope (Vision-Sciences ${ }^{\circledR}$ ENT-2000) to assess the nasal cavities.

Nasal cytology involves: sampling, processing and microscope reading. The sampling requires the collection of cells from the surface of nasal mucosa, which is done by a sterile disposable curette. Samples should be collected from the middle portion of the inferior turbinate. The procedure is performed under anterior rhinoscopy, with an appropriate light source, and the procedure is completely painless. The obtained sample is smeared immediately on a glass slide and it is air-dried. The sample staining is carried out by using the common May-Grünwald-Giemsa (MGG) staining because of its ability to correctly identify the inflammatory nasal cells. The traditional MGG staining procedure requires about 30 minutes. The stained sample is read at optical microscopy, with a 1000x objective with oil immersion. Fifty is 
the minimum number of fields in order to identify a sufficient number of cells. The count of each cell type was expressed by a semi-quantitative grading as it was described previously. ${ }^{21}$ The detection of eosinophils, mast cells, bacteria or fungal ifae clearly identifies a pathological condition. In nasal cytology, bacterial infectious rhinitis is usually characterized by the presence of many neutrophils, with intra and extracellular bacteria that can be easily identified at optical microscopy. Lymphocytes and macrophage can accompany the neutrophilic infiltrate. ${ }^{22}$ Allergic rhinitis (AR) is always characterized by the presence of inflammatory cells (eosinophils, mast cells, neutrophils, and lymphocytes) in the nose. Non-allergic inflammatory rhinitis is defined by the presence of inflammatory cells in the nasal mucosa and by the absence of allergic sensitization. The best known and first described non-allergic rhinitis was NARES: the presence of eosinophils is not only predominant but also massively present with an expression that is even higher than in seasonal rhinitis. Another important type of inflammatory non-allergic rhinitis is NARNE; which is characterized by a massive presence of neutrophils without concomitant bacterial colonization. ${ }^{23}$ Nasal polyps may show an inflammatory pattern, as previously reported. ${ }^{24}$

For the fern test, nasal specimens were taken, as well as the traditional nasal cytology. The collect- ed smears were put on microscope slides and left to dry at room temperature for 10 minutes. They were examined under a phase contrast microscope at $100 \times$ and $400 \times$ magnification and they were classified from type I to type IV according to the Rolando scoring. ${ }^{25}$ In type I (normal pattern), the fern pattern is uniform with closely branching arborization. In type II, the ferns are well distinguished but with less branching. In type III, there are scattered ferns with rare branching, and, in type IV, no fern pattern is seen.

\section{Statistical analysis}

Descriptive statistics were performed and reported in terms of absolute frequencies or percentages for qualitative data and in terms of medians with first and third quartiles (1q-3q) or means with standard deviation for quantitative data. The comparison of frequency distributions was made by means of the chi-square test or the Fisher's exact test in case of expected frequencies $<5$. All tests were two-tailed, and $p$-values $<0.05$ have been considered statistically significant. The analyses were performed using the GraphPad Prism software, GraphPad Software Inc, CA, USA

\section{Results}

Table 1 reports demographic and clinical characteristics of control and patients with different types of

\begin{tabular}{|c|c|c|c|c|c|c|c|c|c|c|c|c|c|c|}
\hline & \multicolumn{2}{|c|}{$\begin{array}{l}\text { Controls } \\
\text { (30) }\end{array}$} & \multicolumn{2}{|c|}{$\begin{array}{l}\text { Patients with } \\
\text { rhinitis } \\
(182)\end{array}$} & \multicolumn{2}{|c|}{$\begin{array}{c}\text { Allergic } \\
\text { rhinitis } \\
(59)\end{array}$} & \multicolumn{2}{|c|}{$\begin{array}{l}\text { Infectious } \\
\text { rhinitis } \\
(32)\end{array}$} & \multicolumn{2}{|c|}{$\begin{array}{c}\text { Nasal polyps } \\
\text { (31) }\end{array}$} & \multicolumn{2}{|c|}{$\begin{array}{l}\text { NARES } \\
(30)\end{array}$} & \multicolumn{2}{|c|}{$\begin{array}{l}\text { NARNE } \\
(30)\end{array}$} \\
\hline $\begin{array}{l}\text { Age } \\
(\text { mean } \pm S D)\end{array}$ & \multicolumn{2}{|c|}{$37.63 \pm 17.87$} & \multicolumn{2}{|c|}{$43.15 \pm 19.03$} & \multicolumn{2}{|c|}{$38.29 \pm 18.46$} & \multicolumn{2}{|c|}{$35.75 \pm 20.36$} & \multicolumn{2}{|c|}{$56.39 \pm 11.57$} & \multicolumn{2}{|c|}{$48.93 \pm 16.38$} & \multicolumn{2}{|c|}{$41.13 \pm 19.84$} \\
\hline \multirow[t]{2}{*}{$\begin{array}{l}\text { Sex } \\
\text { (male/female) }\end{array}$} & \multicolumn{2}{|c|}{$15 / 15$} & \multicolumn{2}{|c|}{$102 / 80$} & \multicolumn{2}{|c|}{$3 / 27$} & \multicolumn{2}{|c|}{$16 / 16$} & \multicolumn{2}{|c|}{$19 / 12$} & \multicolumn{2}{|c|}{$17 / 13$} & \multicolumn{2}{|c|}{$16 / 14$} \\
\hline & $\mathrm{n}$ & $\%$ & $\mathrm{n}$ & $\%$ & $\mathrm{n}$ & $\%$ & $n$ & $\%$ & $\mathrm{n}$ & $\%$ & $\mathrm{n}$ & $\%$ & $\mathrm{n}$ & $\%$ \\
\hline Allergy & 0 & 0 & 89 & 48.90 & 59 & 66.29 & 10 & 11.24 & 12 & 13.48 & 5 & 5.62 & 3 & 3.37 \\
\hline $\begin{array}{l}\text { ASA } \\
\text { sensitivity }\end{array}$ & 0 & 0 & 20 & 10.98 & 1 & 5.00 & 3 & 15.00 & 10 & 50.00 & 4 & 20.00 & 2 & 10.00 \\
\hline Asthma & 0 & 0 & 31 & 17.03 & 10 & 32.26 & 5 & 16.13 & 10 & 32.26 & 4 & 12.90 & 2 & 6.45 \\
\hline Smoke & 0 & 0 & 59 & 32.40 & 11 & 18.64 & 14 & 23.73 & 11 & 18.64 & 12 & 20.34 & 11 & 18.64 \\
\hline Current & & & 48 & 26.40 & 9 & 81.82 & 12 & 85.71 & 8 & 72.73 & 10 & 83.33 & 9 & 81.82 \\
\hline Past & & & 11 & 6.04 & 2 & 18.18 & 2 & 14.29 & 3 & 27.27 & 2 & 16.67 & 2 & 18.18 \\
\hline
\end{tabular}

$\mathrm{NP}=$ nasal polyps, NARES $=$ non-allergic rhinitis with eosinophils, NARNE = non-allergic rhinitis with neutrophils, SD = standard deviation, ASA $=$ acetylsalicylic acid 
rhinitis. Allergic rhinitis was the most frequently diagnosed type of rhinitis (59 out of 182); all the other types of rhinitis i.e. infectious, polyposis, NARNE, NARES were found almost equally among patients. Allergy was a common comorbidity, ASA sensitivity was more frequently present in patients with nasal polyps, asthma was more commonly reported in patients with allergic rhinitis and nasal polyps, and smoking was reported in about $1 / 3$ of patients.

Considering nasal specimens, we found that type II was the most common one in control subjects (76.67\%), whereas type III (59.34 \%), followed by type IV $(28.02 \%)$, was the most frequently observed among patients with rhinitis (figure 1 and table 2). It is worthy of note that no control subject had a type III or type IV fern pattern. The frequency of different fern patterns was significantly different among patients with different types of rhinitis and control subjects $(p=0.0066)$.

In type I fern patterns, only $12.5 \%$ of nasal specimens were collected from patients with rhinitis (i.e. infectious); all the other were isolated from control subjects (87.5\%) (figure 2). More than half of the nasal specimens characterized by type II fern pattern were collected from control subjects, whereas the remaining specimens were recovered from patients with allergic rhinitis, infectious rhinitis, NA-
RES or NARNE (figure 2). Allergic rhinitis was the most frequent type of rhinitis (37.96\%), followed by infectious (19.44 \%) associated to a type III fern pattern. Differently, considering type IV, about $30 \%$ and $25 \%$ of this pattern was found in patients with nasal polyps or in patients with allergic rhinitis, respectively (figure 2).

We also observed that the type of rhinitis that was most commonly found in the most "pathologic" fern patterns, i.e. type III or type IV, was allergic rhinitis, which affected about $1 / 3$ of the patients whose specimens had type III or type IV fern patterns. The other $2 / 3$ were almost equally distributed among the other types of rhinitis (figure 3 ).

In order to verify possible differences in fern patterns between control subjects and patients with rhinitis, we analyzed each type of rhinitis separately. Patients with infectious rhinitis, with NARNE or with allergic rhinitis had a type III fern pattern more frequently, whereas control subjects had a type II pattern more frequently ( $p<0.0001$, each comparison), (data not shown). In patients with NARES or nasal polyps, type III and type IV were the most frequent patterns whereas, in control subjects, type II was predominant ( $<<0.0001$, each comparison).

No statistically significant difference in fern patterns was found in patients with different de-
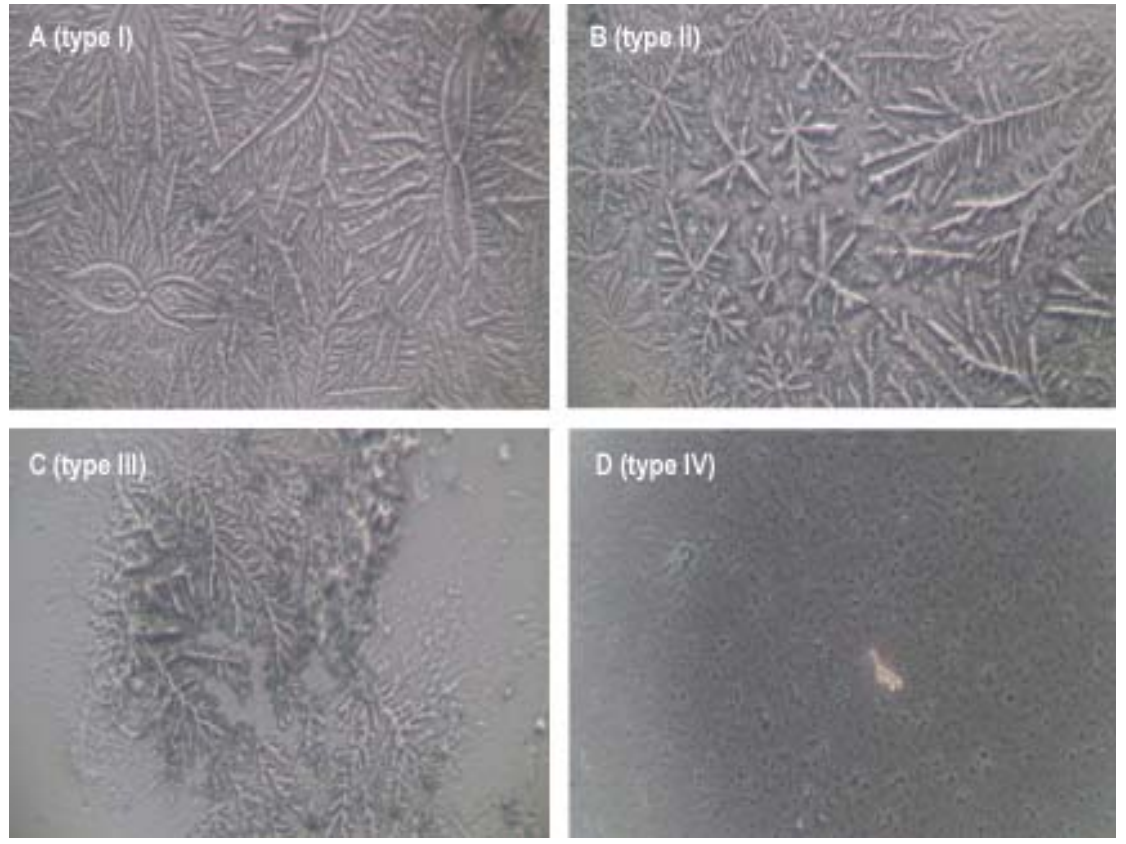

Figure 1. The four grades of nasal ferning taken at 100x magnification, classified from type I to type IV according to the Rolando scoring. ${ }^{25}$ Panel A, type I (normal pattern): the ferning pattern is uniform with closely branching arborization. Panel B, type II: the ferns are well distinguished but with less branching. Panel C, type III: there are scattered ferns with rare branching. Panel D, type IV: no ferning pattern is seen. Light microscope at $400 \times$ magnification. 


\begin{tabular}{|c|c|c|c|c|c|c|c|c|c|}
\hline \multirow{3}{*}{ Study groups } & \multirow{3}{*}{ Disease } & \multicolumn{8}{|c|}{ Ferning type } \\
\hline & & \multicolumn{2}{|c|}{ I } & \multicolumn{2}{|c|}{ II } & \multicolumn{2}{|c|}{ III } & \multicolumn{2}{|c|}{ IV } \\
\hline & & $\mathrm{n}$ & $\%$ & $\mathrm{n}$ & $\%$ & $n$ & $\%$ & $n$ & $\%$ \\
\hline \multirow{6}{*}{$\begin{array}{l}\text { Patients with } \\
\text { rhinitis }\end{array}$} & & 1 & 0.55 & 22 & 12.09 & 108 & 59.34 & 51 & 28.02 \\
\hline & Allergic rhinitis & 0 & 0 & 5 & 8.47 & 41 & 69.49 & 13 & 22.03 \\
\hline & Infectious rhinitis & 1 & 3.13 & 5 & 15.63 & 21 & 65.63 & 5 & 15.63 \\
\hline & NARES & 0 & 0 & 5 & 16.67 & 12 & 40 & 13 & 43.33 \\
\hline & NARNE & 0 & 0 & 7 & 23.33 & 18 & 60 & 5 & 16.67 \\
\hline & nasal polyps & 0 & 0 & 0 & 0 & 16 & 51.61 & 15 & 48.39 \\
\hline Control subjects & & 7 & 23.33 & 23 & 76.67 & 0 & 0 & 0 & 0 \\
\hline
\end{tabular}

grees of nasal eosinophilia or neutrophilia (data not shown).

\section{Discussion}

The definition of rhinitis assumes the concept of an inflammatory reaction; the characteristics of nasal inflammation, mainly regarding the peculiar cellular infiltrate, allow the differentiation of several types of rhinitis. However, a common denominator in inflammatory disorders is the presence of impaired mucus. Altered mucus is per se a pathogenic factor that induces a vicious circle that involves a deterioration of inflammatory disorders.

Nasal cytology is commonly used in clinical practice to define the type of rhinitis, to quantify the cellular infiltrate, and to monitor inflammatory change over time. ${ }^{21}$ Traditionally, the nasal cytology assessment considers cellular presence and morphology, bacteria, and biofilm. However, mucus is a component that is neglected in the treatment of nasal disorders. A possible explanation is the complexity of diagnostic tests able to assess the characteristics of mucus.

In this regard, the fern test could be a very simple and useful method to investigate mucus in patients with rhinitis. The current study, conducted in a real-world setting, such as a Rhinology Unit, proved that rhinitis is associated with impaired fern patterns. In particular, healthy subjects have only type I or II fern patterns and never III or IV. On the

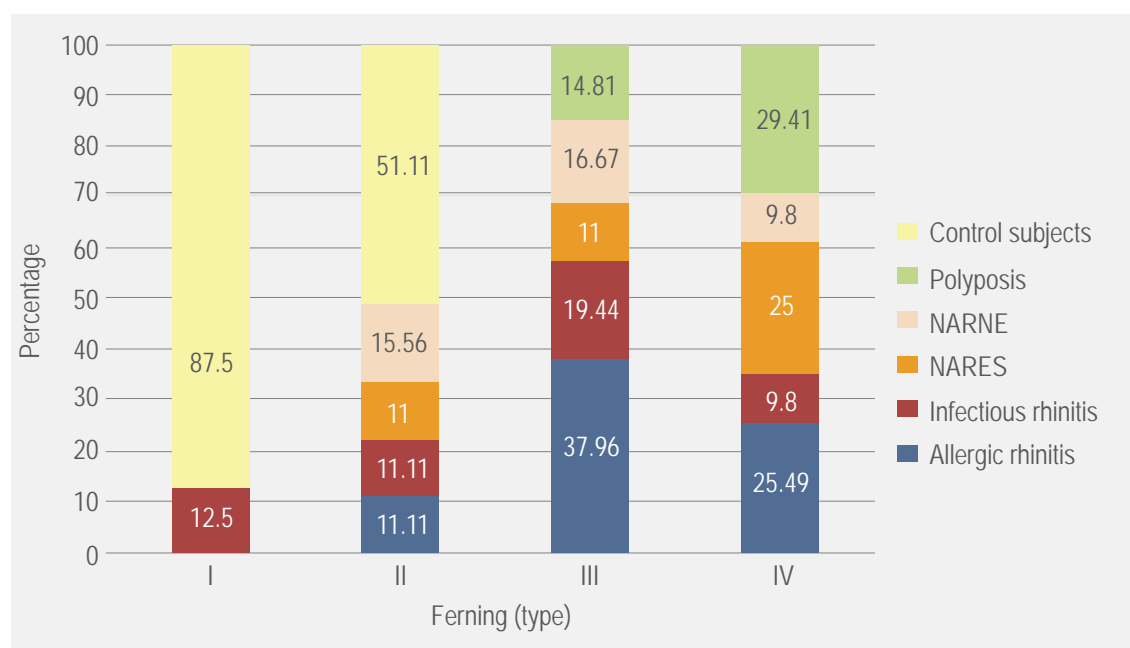

Figure 2. Frequency of different rhinitis within each ferning type. 


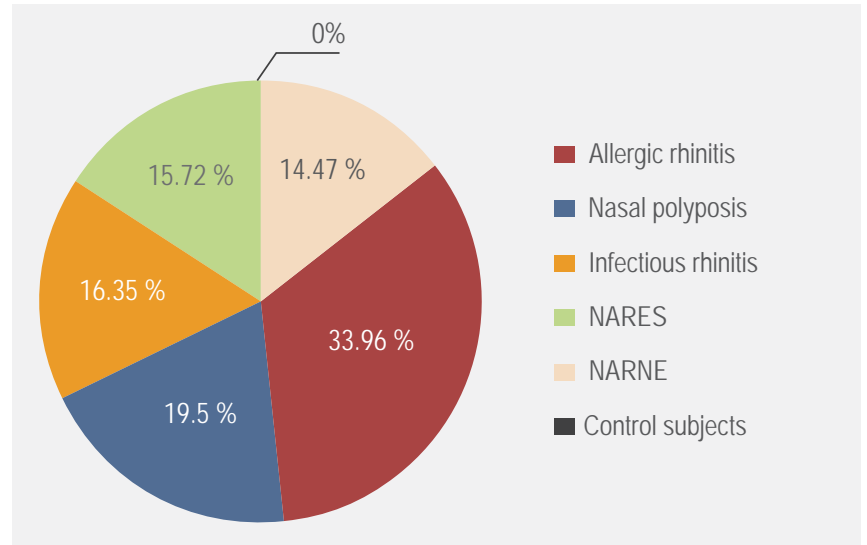

Figure 3. Frequency of different rhinitis in ferning type III or IV. other hand, patients with rhinitis frequently present type III or IV fern patterns. Allergic rhinitis and nasal polyps are most frequently associated with type IV fern patterns. This finding could depend on more intense inflammation, even though a clear-cut relationship between cellular infiltrate and fern pattern was not reported.

The most relevant outcome of the present study is the feasibility of the fern test in the treatment of patients with rhinitis. The fern test may be considered a reliable tool for assessing the characteristics of the mucus, and its findings have clinical relevance. It is conceivable that impaired fern patterns, such as type III and IV, could be the expression of damaged epithelial cells, mainly concerning muciparous cells. In fact, patients with rhinitis usually present altered fern patterns. In other words, type I (and type II) fern patterns could mean the wellness of the epithelium.
However, the present study has some limitations, including the cross-sectional design, the lack of mediator's assessment, and the lack of assessment of clinical symptoms. Therefore, other studies should be designed to fulfill these unmet needs. In particular, it is necessary to correlate the severity of nasal disorders with the type of fern patterns. If a strong relationship between the type of fern pattern and severe symptoms and/or inflammatory aspects exists, this test could be fruitful in phenotyping patients with rhinitis. Therefore, the fern test could be considered a potential biomarker that is useful for defining epithelial damage in nasal disorders. This issue should be properly investigated in further studies.

In conclusion, the fern test could be considered a fruitful method to assess mucus alterations in patients with rhinitis and it could be included as a new parameter in the treatment of rhinitis as a potential biomarker of damaged epithelial cell function.

\section{References}

1. Bansil R, Turner BS. The biology of mucus: composition, synthesis and organization. Adv Drug Deliv Rev. 2018;124:3-15. DOI: 10.1016/j.addr.2017.09.023

2. Taherali F, Varum F, Basit AW. A slippery slope: on the origin, role and physiology of mucus. Adv Drug Deliv Rev. 2018;124:16-33. DOI: 10.1016/j.addr.2017.10.014

3. Lang T, Klasson S, Larsson E, Johansson ME, Hansson GC, Samuelsson T. Searching the evolutionary origin of epithelial mucus protein components-mucins and FCGBP. Mol Biol Evol. 2016;33(8):19211936. DOI: $10.1093 / \mathrm{molbev} / \mathrm{msw} 066$

4. Cone RA. Barrier properties of mucus. Adv Drug Deliv Rev. 2009;61(2):75-85. DOI: 10.1016/j. addr.2008.09.008

5. Silberberg A. On mucociliary transport. Biorheology. 1990;27(3-4):295-307. DOI: 10.3233/BIR-1990273-408 
6. Neutra MR, Forstner JF. Gastrointestinal mucus: synthesis, secretion, and function. In: Johnson LR (editor). Physiology of the gastrointestinal tract. EEUU: Raven Press; 1987.

7. Quraishi MS, Jones NS, Mason J. The rheology of nasal mucus: a review. Clin Otolaryngol Allied Sci. 1998;23(5):403-413. DOI: 10.1046/j.1365-2273.1998.00172.x

8. Lai SK, Wang YY, Wirtz D, Hanes J. Micro- and macrorheology of mucus. Adv Drug Deliv Rev. 2009;61(2):86-100. DOI: 10.1016/j.addr.2008.09.012

9. Carlstedt I, Sheehan JK. Structure and macromolecular properties of cervical mucus glycoproteins. Symp Soc Exp Biol. 1989;43:289-316.

10. Thornton DJ, Sheehan JK. From mucins to mucus: toward a more coherent understanding of this essential barrier. Proc Am Thorac Soc. 2004;1(1):54-61. DOI: 10.1513/pats.2306016

11. Papanicolaou GN. Mucus test. Anat Rec. 1945;91:293.

12. Roland M. A simple test for the determination of ovulation, estrogen activity, and early pregnancy using the cervical mucus secretion; a preliminary report. Am J Obstet Gynecol. 1952;63(1):81-89. DOI: 10.1016/S0002-9378(16)38983-9

13. Zondek B, Rozin S. Cervical mucus arborization; its use in the determination of corpus luteum function. Obstet Gynecol. 1954;3(5):463-470. DOI: 10.1097/00006254-195508000-00049

14. Abou-Shabanah EH, Plotz EJ. A biochemical study of the cervical and nasal mucus fern phenomenon. Am J Obs Gynecol. 1957;74(3):559-568. DOI: 10.1016/0002-9378(57)90508-2

15. Rolando M. Tear mucus ferning test in normal and keratoconjunctivitis sicca eyes. Chibret Int J Ophthalmol. 1984;2:33-41.

16. Rolando M, Baldi F, Zingirian M. The effect of hyperosmolarity on tear mucus ferning. Fortschr Ophthalmol. 1986;83(6):644-646.

17. Rolando M, Baldi F, Calabria G. Tear mucus crystallization in children with cystic fibrosis. Ophthalmologica. 1988;197(4):202-206. DOI: 10.1159/000309944

18. Kalayci D, Kiper N, Ozcelik U, Gocmen A, Hasiripi H. Clinical status, ocular surface changes and tear ferning in patients with cystic fibrosis. Acta Ophthalmol Scand. 1996;74(6):563-565. DOI: 10.1111/j.16000420.1996.tb00735.x

19. Horwath J, Ettinger K, Bachernegg M, Bodner E, Schmut O. Ocular Ferning Test - effect of temperature and humidity on tear Ferning patterns. Ophthalmologica. 2001;215(2):102-107. DOI: 10.1159/000050838

20. Lavaud MC, Trouillas J. The mucus: a medium of life. Gynecol Obstet Fertil. 2012;40(1):19-23. DOI: 10.1016/j.gyobfe.2011.07.031

21. Gelardi M. Atlas of nasal cytology. Second edition. Milan, Italy: Edi Ermes; 2012.

22. Gelardi M, Fiorella ML, Russo C, Fiorella R, Ciprandi G. Role of nasal cytology. Int J Immunopathol Pharmacol. 2010;23(Suppl 1):45-49.

23. Gelardi M, Maselli-Del-Giudice A, Fiorella ML, Fiorella R, Russo C, Soleti P, et al. Non-allergic rhinitis with eosinophils and mast cells constitutes a new severe nasal disorder. Int J Immunopathol Pharmacol. 2008;21(2):325-331. DOI: 10.1177/039463200802100209

24. Gelardi M, lannuzzi L, De-Giosa M, Taliente S, DeCandia N, Quaranta N,et al. Non-surgical management of chronic rhinosinusitis with 1 nasal polyps based on clinical cytological grading: a precision medicinebased approach. Acta Otorhinolaryngol Ital. 2017;37(1):38-45. DOI: 10.14639/0392-100X-1417

25. Rolando M. Tear mucus ferning test in normal and keratoconjunctivitis sicca eyes. Chibret Int J Ophthalmol. 1984;2:32-41. 